University of Maryland Francis King Carey School of Law

DigitalCommons@UM Carey Law

7-2014

\title{
Consequences for Cleanup: EPA Gets Serious about Weak Watershed Improvement Plans
}

Rena I. Steinzor

University of Maryland Francis King Carey School of Law, rsteinzor@law.umaryland.edu

Anne Havemann

Follow this and additional works at: https://digitalcommons.law.umaryland.edu/fac_pubs

Part of the Environmental Law Commons, and the Water Law Commons

\section{Digital Commons Citation}

Center for Progressive Reform Issue Alert no. 1405, July 2014.

This Working Paper is brought to you for free and open access by the Francis King Carey School of Law Faculty at DigitalCommons@UM Carey Law. It has been accepted for inclusion in Faculty Scholarship by an authorized administrator of DigitalCommons@UM Carey Law. For more information, please contact smccarty@law.umaryland.edu. 


\title{
Consequences for Cleanup: EPA Gets Serious about Weak Watershed Improvement Plans
}

\author{
by CPR President Rena Steinzor
} and

CPR Chesapeake Bay Policy Analyst Anne Havemann

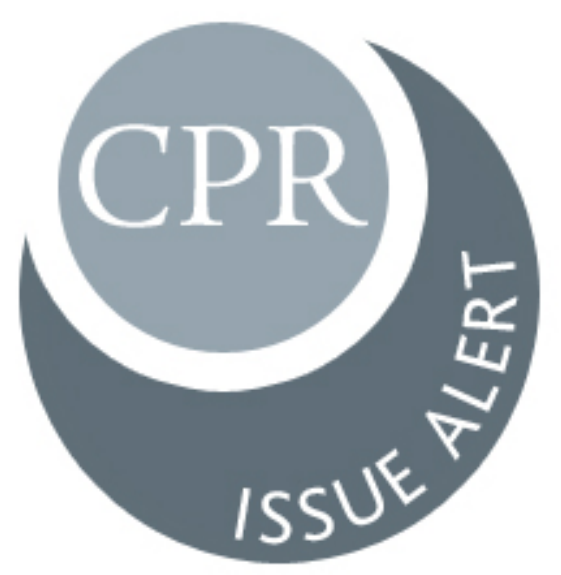

(C) Center for Progressive Reform Issue Alert \#1405

July 2014

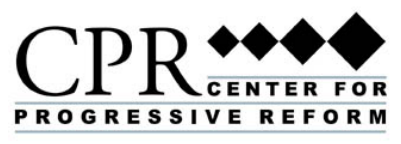




\section{Issue Alert: \\ Consequences for Cleanup: EPA Gets Serious about Weak \\ Watershed Improvement Plans}

\section{Introduction}

In a landmark series of reports issued on June 26, 2014, the Environmental Protection Agency (EPA) put the seven jurisdictions that pollute the Chesapeake Bay on notice that their plans for reducing nitrogen, phosphorous, and sediment fall short of where they must be to make cleanup by 2025 a reality. By EPA's reckoning, Pennsylvania and Delaware were furthest off the mark, but Maryland, New York, Virginia, and West Virginia face EPA action if they fail to substantially improve their plans. Of the seven jurisdictions, only Washington, D.C. escaped serious criticism.

The Chesapeake Bay is the largest estuary in North America, home to more than 3,600 species of plants and animals. The Bay watershed - the land that drains into the Bayencompasses parts of six states and Washington, D.C. This national treasure has been deteriorating since the 1930s. For three decades, states within the Chesapeake Bay watershed collaborated their way to nowhere, inking voluntary agreements to clean up the Bay that resulted in very little actual progress. Then the Obama administration's Environmental Protection Agency (EPA) stepped up to the plate, issuing a Total Maximum Daily Load (TMDL), or pollution diet, for the Chesapeake. ${ }^{1}$ Under its terms, the seven jurisdictions must have in place 60 percent of all the measures needed to reduce nitrogen, phosphorous, and sediment deposition in the Bay and its tributaries by 2017. By 2025, 100 percent of those measures are due. To make sure the deadlines are met, states develop two-year milestone commitments, which are subject to EPA review.

In its review of the states' 2014-15 milestone commitments, the agency found that planned reductions in nitrogen fell short of reaching the TMDL's 2017 target by nearly 6 million pounds. ${ }^{2}$ The most prevalent shortcomings involved inadequate urban/suburban stormwater management; of the seven jurisdictions, only Delaware had sufficient measures in place to reduce this pollutant. EPA also found the systems for tracking pollution reductions in all jurisdictions but Virginia lacking. Of the seven jurisdictions, EPA found the milestones submitted by Pennsylvania and Delaware to be the least sufficient. Pennsylvania's failure to rein in pollution is particularly concerning since Pennsylvania is the source of about half of the nitrogen that makes its way into the Bay.

The main difference between the earlier, ineffective interstate agreements and EPA's pollution diet is that the federal agency is squarely in charge of making sure states are following the pollution diet. If a state veers off track, EPA can create negative incentives for them to redouble their efforts. These actions include redirecting or placing conditions on EPA grants, expanding the requirement to obtain permits to previously unregulated sources, and increasing federal enforcement in the watershed. ${ }^{3}$ 
On the strength of EPA's newly released assessment, the agency will immediately increase its oversight of Pennsylvania's agriculture sector. The agency has also proposed increasing its oversight of specific sectors in Delaware, Maryland, and Virginia unless the states meet certain conditions.

EPA is bound to get pushback from recalcitrant states, making it all the more important that it stick to its guns. States that are not on track to meet the pollution diet must face consequences if we are to achieve any progress in restoring the Chesapeake Bay.

\section{Background: Components of the Pollution Diet}

The Clean Water Act (CWA) requires states and EPA to take up to three steps to protect water quality. First, discernible point sources - pipes and channels, for example - must get a permit to discharge pollution into water bodies. This permitting system is known as the National Pollution Discharge Elimination System (NPDES). The NPDES permits contain effluent limits that are based on the best available technology. ${ }^{4}$ Second, states are required to develop water quality standards. To develop this standard, a state first delineates what the water body is used for-recreation, agriculture, or industry, for example - and then sets criteria articulating acceptable levels of pollution in light of the designated use. ${ }^{5}$ These standards enable states to target nonpoint sources, runoff from farms for example, that are not subject to NPDES permitting requirements. Areas where water-quality goals have not been attained are considered "impaired." Inclusion on a state's impaired waters list triggers the third step - the statutory requirement to establish a TMDL for that water body. ${ }^{6}$

EPA has established tens of thousands of pollution diets in other parts of the country, and the Bay-wide TMDL is actually a combination of 92 smaller TMDLs for individual Chesapeake Bay tidal segments. The Bay-wide TMDL is the largest and most ambitious TMDL in the country. In establishing the TMDL, EPA set limits on the quantities of pollutants that could be discharged into the water and allocated the total permissible amount of each pollutant among the jurisdictions within the watershed. The states then developed long-term plans, known as Watershed Implementation Plans (WIPs), detailing how they would achieve the targets by the 2017 and 2025 deadlines. To ensure that efforts stay on track, the states also agreed to shorter, two-year milestone commitments.

The milestones contain numeric and narrative goals for reducing nutrient and sediment runoff from specific sectors. For the agriculture sector, the milestones generally contain targets for how many acres of cover crops and streamside fencing will be established during the two-year period, among other best management practices (BMPs). They often lay out specifics on how states plan to regulate industrial animal farms, including how many permits they will issue and how many inspections they will conduct. ${ }^{7}$

For the urban and suburban stormwater sector, the milestones might contain specific targets for the number of rain barrels, green roofs, and rain gardens installed; number of trees planted; and number of acres retrofitted with low impact development techniques. ${ }^{8}$ 
The wastewater sector encompasses wastewater treatment plants (WWTPs) and individual septic systems, and the commitments often lay out a timeline for renewing permits for WWTPs, establish timetables for inspections, and set specific goals for denitrification and new sewer connections. ${ }^{9}$

In addition, the milestones describe states' plans to offset pollution resulting from new growth, and may include nutrient trading provisions. ${ }^{10}$ Many of the milestones describe how states will improve the systems they use to track pollution reductions and BMP implementation. ${ }^{11}$

The milestone commitments are a critical accountability tool, allowing EPA and citizens to monitor jurisdictions' progress toward meeting the Bay pollution diet. For each set of milestones, EPA evaluates whether the proposed actions are enough to keep the jurisdictions on track to meet the 2017 and 2025 deadlines. In January 2012, the jurisdictions submitted to EPA the first set of two-year milestones covering 2012-13. ${ }^{12}$ In February 2012, EPA reported on the sufficiency of those targets. ${ }^{13}$ The jurisdictions submit periodic reports to EPA on their progress, which are also made available to the public. ${ }^{14}$ The jurisdictions reported on their 2012-13 programmatic milestone achievements in January 2014 and, in May 2014, submitted their final 2014-15 milestones to EPA. ${ }^{15}$

\section{EPA Evaluations Show Several States Lagging, Propose Actions}

On June $26^{\text {th }}, 2014$, EPA released its analysis of the states' progress toward the 2012-13 milestone commitments and its evaluation of the 2014-15 milestones. Overall, EPA found that the jurisdictions met the 2013 milestone targets for nitrogen and phosphorus but fell short of their reduction commitments for sediment. ${ }^{16}$ As for the 2014-15 milestone commitments, the agency found that the jurisdictions remain on track to reduce phosphorus and sediment, but are veering dangerously off course with respect to nitrogen reductions. $^{17}$

Of the seven jurisdictions subject to the pollution diet, EPA found the milestones submitted by Pennsylvania and Delaware to be the least sufficient. According to EPA, Delaware has fallen behind on permitting industrial animal farms and WWTPs. ${ }^{18}$ Pennsylvania's plans for reducing stormwater pollution were not on track, nor were its plans to address pollution from the agriculture sector. ${ }^{19}$ Pennsylvania's failure to rein in pollution from farms was particularly concerning because Pennsylvania is the source of about half of the nitrogen that makes its way into the Bay and the state is counting on achieving 75 percent of its necessary reductions from the agriculture sector. EPA faulted both Delaware and Pennsylvania for sitting on substantial sums of already-awarded grant money, and called on them to use it to get their programs back on track.

Overall, the milestones' most prevalent shortcomings involved urban/suburban stormwater management. Of the seven jurisdictions, only Delaware had sufficient plans 
in place in the agency's judgment. EPA also found that all states except Virginia lacked the ability to accurately track implementation efforts. Three of the jurisdictionsDelaware, Pennsylvania, and Virginia-fell short on controlling pollution from the agriculture sector. EPA also called on Delaware, New York, and Virginia to improve wastewater management.

The TMDL process stands apart from earlier cooperative agreements that yielded few results in that the TMDL has teeth. The agency can engage in three levels of oversight, from ongoing to enhanced to taking backstop actions. In states where EPA has concerns that pollution reductions may not be achieved in certain sectors, the agency enhances its oversight by putting the jurisdictions on notice that it will consider future backstops unless specific near-term progress is demonstrated. Backstop actions are the next level in EPA oversight. While the actions vary depending on a state's shortcomings, they include measures like adjusting a state's pollution allocation for a specific sector or expanding the requirement to obtain permits to previously unregulated sources. ${ }^{20}$

With these evaluations, EPA demonstrated its willingness to use its teeth and take action against states that are not on track to meet their targets. The agency will dramatically increase its oversight of Pennsylvania's agriculture sector and will continue backstop oversight in the stormwater sector and enhanced oversight of the state's trading and offset plans. In Delaware, the agency is considering enhanced oversight in the agriculture and wastewater sector. In West Virginia, the agency will continue targeted enforcement of stormwater permits and enhanced oversight of the agriculture sector. It is also considering enhancing its oversight of West Virginia's stormwater sector. The agency announced that it will continue enhanced oversight of Virginia's stormwater sector, and that it might increase its oversight of the stormwater sector in Maryland. EPA will also place terms on current grants in Delaware, Maryland, Pennsylvania, and Virginia and indicated that failure to meet the terms may affect future grants.

The agency's findings for each watershed jurisdiction are outlined in the charts below. 
Washington, D.C. ${ }^{21}$

\begin{tabular}{|c|c|c|c|c|}
\hline & Nitrogen & Phosphorus & Sediment & Notes \\
\hline $\begin{array}{l}\text { Did the state achieve } \\
\text { its } 2012-13 \\
\text { milestone targets? }\end{array}$ & Yes & Yes & Yes & $\begin{array}{l}\text { Progress made } \\
\text { in urban } \\
\text { stormwater \& } \\
\text { wastewater } \\
\text { sectors }\end{array}$ \\
\hline \multirow[t]{2}{*}{$\begin{array}{l}\text { Are the state's } \\
2014-15 \text { targets on } \\
\text { track to meet } 2017 \\
\text { reduction goals? }\end{array}$} & Yes & No & No & \\
\hline & Agriculture & Stormwater & Wastewater & Trading/Offsets \\
\hline $\begin{array}{l}2014 \text { Oversight } \\
\text { Status }\end{array}$ & $\mathrm{N} / \mathrm{a}$ & Ongoing & Ongoing & Ongoing \\
\hline Recommendations & \multicolumn{4}{|c|}{$\begin{array}{l}\text { - Improve implementation of tree plantings and redevelopment } \\
\text { projects in the urban stormwater sector } \\
\text { - Improve tracking, verification and reporting of BMPs }\end{array}$} \\
\hline EPA Action & \multicolumn{4}{|c|}{$\begin{array}{l}\text { - EPA will work cooperatively with the District to implement the } \\
\text { milestone commitments }\end{array}$} \\
\hline
\end{tabular}




\section{Delaware $^{22}$}

\begin{tabular}{|c|c|c|c|c|}
\hline 12 & Nitrogen & Phosphorus & Sediment & Notes \\
\hline $\begin{array}{l}\text { Did the state achieve } \\
\text { its } 2012-13 \text { milestone } \\
\text { targets? }\end{array}$ & Nearly & 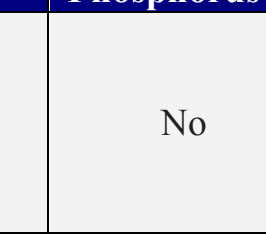 & No* & $\begin{array}{l}\text { Progress made } \\
\text { in the } \\
\text { agriculture and } \\
\text { stormwater } \\
\text { sectors }\end{array}$ \\
\hline $\begin{array}{l}\text { Are the state's } 2014- \\
15 \text { targets on track to } \\
\text { meet } 2017 \text { reduction } \\
\text { goals? }\end{array}$ & No & Yes & Yes & \\
\hline & Agriculture & Stormwater & Wastewater & Trading/Offsets \\
\hline $\begin{array}{l}2014 \text { Oversight } \\
\text { Status }\end{array}$ & $\begin{array}{l}\text { Ongoing/ } \\
\text { Enhanced }\end{array}$ & Ongoing & $\begin{array}{l}\text { Ongoing/ } \\
\text { Enhanced }\end{array}$ & Ongoing \\
\hline Recommendations & $\begin{array}{ll}\text { - } & \text { Place addi } \\
\text { agriculture } \\
\text { nitrogen ta } \\
\text { - } & \text { Reissue all } \\
\text { - } & \text { Improve tr } \\
\text { agriculture } & \text { Delaware } \\
\text { implement } \\
\text { remedying }\end{array}$ & $\begin{array}{l}\text { lal emphasis on in } \\
\text { d wastewater sect } \\
\text { ts } \\
\text { pired WWTP per } \\
\text { ing, verification, } \\
\text { ctor } \\
\text { not spent much o } \\
\text { y restoration mea } \\
\text { flaws identified }\end{array}$ & $\begin{array}{l}\text { ving impleme } \\
\text { to get back on } \\
\text { by the end of } \\
\text { reporting of } \\
\text { grants it has } \\
\text { s, and should } \\
\text { PA in this ev }\end{array}$ & $\begin{array}{l}\text { ation in the } \\
\text { ack to meet } \\
014 \\
\text { IPs, especially in } \\
\text { ceived to } \\
\text { end it on } \\
\text { lation }\end{array}$ \\
\hline EPA Action & $\begin{array}{l}\text { EPA may } \\
\text { ongoing to } \\
\text { conditions } \\
\text { - } \quad \text { EPA will i } \\
\text { CAFO and } \\
\text { outputs on } \\
\text { - For other } \\
\text { maintain o }\end{array}$ & $\begin{array}{l}\text { vngrade the agrict } \\
\text { hanced oversight } \\
\text { rporate outputs a } \\
\text { WTP permits on } \\
\text { edule may affect } \\
\text { ors, EPA will wor } \\
\text { ing oversight }\end{array}$ & $\begin{array}{l}\text { e and wastew } \\
\text { ss Delaware } 1 \\
\text { eadlines for th } \\
\text { ent grants. Fai } \\
\text { re grants } \\
\text { ooperatively }\end{array}$ & $\begin{array}{l}\text { er sector from } \\
\text { ets certain } \\
\text { issuance of } \\
\text { re to provide } \\
\text { h the state to }\end{array}$ \\
\hline
\end{tabular}

* The state set its milestone target for sediment above its final 2025 goal. So, while Delaware did not meet this milestone target, it has already met its 2025 WIP sediment allocation. 


\begin{tabular}{|c|c|c|c|c|}
\hline \multirow[b]{3}{*}{$\begin{array}{l}\text { Are the state's } 2014- \\
15 \text { targets on track to } \\
\text { meet } 2017 \text { reduction } \\
\text { goals? }\end{array}$} & Nitrogen & Phosphorus & Sediment & \multirow[b]{2}{*}{$\begin{array}{l}\text { Progress due to } \\
\text { record cover crops } \\
\text { planted, } \\
\text { wastewater } \\
\text { treatment plant } \\
\text { upgrades and } \\
\text { implementation of } \\
\text { the Fertilizer Use } \\
\text { Act of } 2011 .\end{array}$} \\
\hline & Yes & Yes & Yes & \\
\hline & Yes & Yes & Yes & \\
\hline & Agriculture & Stormwater & Wastewater & Trading/Offsets \\
\hline $\begin{array}{l}2014 \text { Oversight } \\
\text { Status }\end{array}$ & Ongoing & $\begin{array}{l}\text { Ongoing/ } \\
\text { Enhanced }\end{array}$ & Ongoing & Ongoing \\
\hline Recommendations & $\begin{array}{ll}\text { - } & \text { Adhere to } \\
\text { - } & \text { stormwat } \\
\text { - } & \text { Dinalize r } \\
\text { - } & \text { Improvelop } \\
\end{array}$ & $\begin{array}{l}\text { agreed-upon sched } \\
\text { PDES permits } \\
\text { ed stormwater retr } \\
\text { dule for adopting } \\
\text { ing, verification, a }\end{array}$ & $\begin{array}{l}\text { of when to is } \\
\text { guidance } \\
\text { ounting for } \mathrm{G} \\
\text { reporting of I }\end{array}$ & $\begin{array}{l}\text { sue expired } \\
\text { srowth regulations } \\
\text { BMPs }\end{array}$ \\
\hline EPA Action & 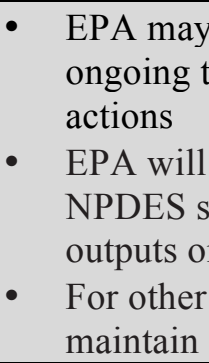 & $\begin{array}{l}\text { hangade the urban/ } \\
\text { hanced oversight } \\
\text { rporate outputs an } \\
\text { water permits on } \\
\text { hedule may affect } \\
\text { ors, EPA will wor } \\
\text { ing oversight }\end{array}$ & $\begin{array}{l}\text { urban stormy } \\
\text { ss Maryland } \\
\text { eadlines for t } \\
\text { ent grants. Fa } \\
\text { ire grants } \\
\text { ooperatively }\end{array}$ & $\begin{array}{l}\text { vater sector from } \\
\text { takes specific } \\
\text { he issuance of } \\
\text { ailure to provide } \\
\text { with the state to }\end{array}$ \\
\hline
\end{tabular}




\begin{tabular}{|c|c|c|c|c|}
\hline & Nitrogen & Phosphorus & Sediment & Notes \\
\hline $\begin{array}{l}\text { Did the state achieve } \\
\text { its } 2012-13 \text { milestone } \\
\text { targets? }\end{array}$ & Yes & Yes & Yes & $\begin{array}{l}\text { Steady nutrient } \\
\text { and sediment } \\
\text { reductions in } \\
\text { agriculture. }\end{array}$ \\
\hline $\begin{array}{l}\text { Are the state's } 2014- \\
15 \text { targets on track to } \\
\text { meet } 2017 \text { reduction } \\
\text { goals? }\end{array}$ & No & Yes & Yes & \\
\hline & Agriculture & Stormwater & Wastewater & Trading/Offsets \\
\hline $\begin{array}{l}2014 \text { Oversight } \\
\text { Status }\end{array}$ & Ongoing & Ongoing & Enhanced & Ongoing \\
\hline Recommendations & \multicolumn{4}{|c|}{$\begin{array}{l}\text { - Issue general permit and regulations for industrial animal farms } \\
\text { - Place additional emphasis on improving capacity, implementation } \\
\text { and reporting in wastewater and stormwater sectors. } \\
\text { - Increase nitrogen reductions from wastewater commensurate w/ } \\
\text { other states } \\
\text { - Ensure that general permits for construction and stormwater, to be } \\
\text { - } \text { reissued in 2015, are consistent with Bay TMDL } \\
\text { - Improve tracking, verification, and reporting of BMPs }\end{array}$} \\
\hline EPA Action & \multicolumn{4}{|c|}{$\begin{array}{l}\text { EPA will maintain enhanced oversight for wastewater sector } \\
\text { For other sectors, EPA will work cooperatively with the state to } \\
\text { maintain ongoing oversight }\end{array}$} \\
\hline
\end{tabular}




\begin{tabular}{|c|c|c|c|c|}
\hline & Nitrogen & Phosphorus & Sediment & Notes \\
\hline $\begin{array}{l}\text { Did the state achieve } \\
\text { its } 2012-13 \text { milestone } \\
\text { targets? }\end{array}$ & No & Yes & No & $\begin{array}{l}\text { Progress in the } \\
\text { agriculture and } \\
\text { wastewater } \\
\text { sectors }\end{array}$ \\
\hline $\begin{array}{l}\text { Are the state's } 2014- \\
15 \text { targets on track to } \\
\text { meet } 2017 \text { reduction } \\
\text { goals? }\end{array}$ & No & Yes & Yes & \\
\hline & Agriculture & Stormwater & Wastewater & Trading/Offsets \\
\hline $\begin{array}{l}2014 \text { Oversight } \\
\text { Status }\end{array}$ & Backstop & Backstop & Ongoing & Enhanced \\
\hline Recommendations & 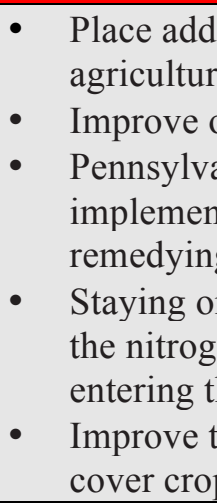 & $\begin{array}{l}\text { al emphasis on in } \\
\mathrm{d} \text { stormwater sect } \\
\text { ts and trading pro } \\
\text { has not spent muc } \\
\text { y restoration mea } \\
\text { e flaws identified } \\
\text { ick is critical, beca } \\
26 \% \text { of the phosph } \\
\text { hesapeake Bay } \\
\text { ing, verification, } \\
\text { nd manure transpo }\end{array}$ & $\begin{array}{l}\text { ving impleme } \\
\text { f the grants it } \\
\text { s, and should } \\
\text { PA in this ev } \\
\text { state is respo } \\
\text { s and } 31 \% \text { of } \\
\text { reporting of } \mathrm{S}\end{array}$ & $\begin{array}{l}\text { ntation in the } \\
\text { has received to } \\
\text { spend it on } \\
\text { aluation } \\
\text { nsible for } 46 \% \text { of } \\
\text { the sediment load } \\
3 \text { MPs, especially }\end{array}$ \\
\hline EPA Action & 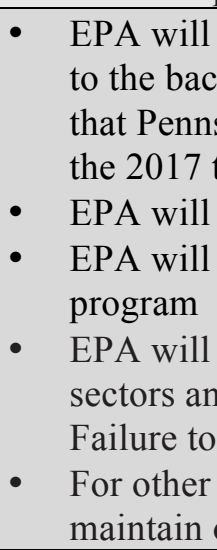 & $\begin{array}{l}\text { ngrade the agricu } \\
\text { p category becaus } \\
\text { ania is not on trac } \\
\text { et } \\
\text { ntain backstop act } \\
\text { ntain enhanced ov } \\
\text { orporate outputs ar } \\
\text { ate's MS4 and urb } \\
\text { vide outputs on sc } \\
\text { ors, EPA will wor } \\
\text { oing oversight }\end{array}$ & $\begin{array}{l}\text { sector from } \\
\text { riculture mile } \\
\text { have practice } \\
\text { level for stor } \\
\text { ght of trading } \\
\text { eadlines for th } \\
\text { orograms into } \\
\text { ule may affec } \\
\text { operatively v }\end{array}$ & $\begin{array}{l}\text { enhanced oversight } \\
\text { stones demonstrate } \\
\text { s in place to meet } \\
\text { mwater sector } \\
\text { and offset } \\
\text { e agricultural } \\
\text { current grants. } \\
\text { tuture grants } \\
\text { ith the state to }\end{array}$ \\
\hline
\end{tabular}




\begin{tabular}{|c|c|c|c|c|}
\hline & Nitrogen & Phosphorus & Sediment & Notes \\
\hline $\begin{array}{l}\text { Did the state achieve } \\
\text { its } 2012-13 \text { milestone } \\
\text { targets? }\end{array}$ & Yes & Yes & Yes & $\begin{array}{l}\text { Greater than } \\
\text { expected } \\
\text { wastewater } \\
\text { reductions. }\end{array}$ \\
\hline \multirow[t]{2}{*}{$\begin{array}{l}\text { Are the state's } 2014- \\
15 \text { targets on track to } \\
\text { meet } 2017 \text { reduction } \\
\text { goals? }\end{array}$} & Yes & Yes & Yes & \\
\hline & Agriculture & Stormwater & Wastewater & Trading/Offsets \\
\hline $\begin{array}{l}2014 \text { Oversight } \\
\text { Status }\end{array}$ & Ongoing & Enhanced & Ongoing & Ongoing \\
\hline Recommendations & $\begin{array}{l}\text { - } \begin{array}{l}\text { Place add } \\
\text { agricultur }\end{array} \\
\end{array}$ & $\begin{array}{l}\text { lal emphasis on im } \\
\text { ormwater and sept }\end{array}$ & $\begin{array}{l}\text { sing implem } \\
\text { sectors }\end{array}$ & entation in \\
\hline EPA Action & $\begin{array}{l}\text { EPA will } \\
\text { stormwat } \\
\text { EPA will } \\
\text { Phase I } \\
\text { of the cor } \\
\text { grants. Fr } \\
\text { grant awc } \\
\text { For other } \\
\text { maintain } \\
\end{array}$ & $\begin{array}{l}\text { ntain enhanced ov } \\
\text { ctor } \\
\text { rporate outputs an } \\
\text { permits, CAFO pe } \\
\text { ction general perm } \\
\text { e to provide output } \\
\text { ors, EPA will wor } \\
\text { ing oversight }\end{array}$ & $\begin{array}{l}\text { ight of urban/s } \\
\text { leadlines for tl } \\
\text { ts and the pha } \\
\text { coverage syste } \\
\text { n schedule co } \\
\text { ooperatively v }\end{array}$ & $\begin{array}{l}\text { suburban } \\
\text { he issuance of } \\
\text { sed development } \\
\text { m into existing } \\
\text { uld affect future } \\
\text { vith the state to }\end{array}$ \\
\hline
\end{tabular}


West Virginia ${ }^{27}$

\begin{tabular}{|l|c|c|c|l|}
\hline \multicolumn{1}{c}{ Nitrogen } & Phosphorus & Sediment & \multicolumn{1}{c|}{ Notes } \\
\hline $\begin{array}{l}\text { Did the state achieve } \\
\text { its 2012-13 milestone } \\
\text { targets? }\end{array}$ & Yes & Yes & No* & $\begin{array}{l}\text { Progress in the } \\
\text { agriculture and } \\
\text { wastewater } \\
\text { sectors }\end{array}$ \\
$\begin{array}{l}\text { Are the state's 2014- } \\
\begin{array}{l}\mathbf{1 5} \text { targets on track to } \\
\text { meet 2017 reduction } \\
\text { goals? }\end{array}\end{array}$ & No & Yes & Yes & \\
\hline
\end{tabular}

\begin{tabular}{|l|c|c|c|c|}
\hline $\begin{array}{l}\text { 2014 Oversight } \\
\text { Status }\end{array}$ & Enhiculture & Stormwater & Wastewater & Trading/Offsets \\
\cline { 2 - 5 } & $\begin{array}{c}\text { Ongoing/ } \\
\text { Enhanced }\end{array}$ & Ongoing & Ongoing \\
\hline
\end{tabular}

Recommendations

- Conduct a planned comprehensive assessment of new growth and nutrient loadings for stormwater

- Continue implementation of CAFO program and strengthen voluntary agriculture programs

- Improve tracking, verification, and reporting of BMPs

EPA Action

- EPA may downgrade the urban/suburban stormwater sector from ongoing to enhanced oversight in 2015 if assessment of new growth and nutrient loads shows that urban loads will not meet the Bay TMDL allocations and state does not demonstrate that additional actions will be taken to reduce increased loads

- EPA will maintain enhanced oversight of agriculture sector

- EPA will continue targeted enforcement of stormwater permits

- For other sectors, EPA will work cooperatively with the state to maintain ongoing oversight

* The state set its milestone target for sediment above its final 2025 goal. So, while West Virginia did not meet this milestone target, it has already met its 2025 WIP sediment allocation.

\section{Conclusion}

The milestone commitments are a critical accountability tool, allowing EPA and citizens to monitor states' progress toward meeting the Bay pollution diet. Commitments contained in the 2014-15 milestones show that some states are not keeping up. With its recent evaluations, EPA showed its willingness to hold the states accountable by increasing oversight or withholding grants. As the history of Chesapeake Bay restoration efforts reveals, without consequences, some states will not hold up their end of the bargain. The TMDL process is steadily marching towards the finish line, and EPA is playing a critical role in ensuring that each state keeps up. 


\section{Endnotes}

${ }^{1}$ Envtl. Protection Agency, Chesapeake Bay TMDL (Dec. 29, 2010), available at http://www.epa.gov/reg3wapd/tmdl/ChesapeakeBay/tmdlexec.html.

${ }^{2}$ Press Release, Envtl. Protection Agency, EPA Credits States for Making Progress in Bay Cleanup; Says More Effort Needed to Get Back on Track for a Restored Bay (June 26, 2014, available at

http://yosemite.epa.gov/opa/admpress.nsf/90829d899627a1d98525735900400c2b/d6fc92 040ef8cc4585257d03005d7199! OpenDocument.

${ }^{3}$ For a full list of potential actions EPA may take to ensure that jurisdictions develop and implement appropriate WIPs, attain appropriate two-year milestones of progress, and provide timely and complete information, see ENVTL. PROTECTION AGENCY, CheSAPEAKE BAY TMDL, § 7.2.4 Federal EPA Actions (Dec. 29, 2010), available at http://www.epa.gov/reg3wapd/pdf/pdf chesbay/FinalBayTMDL/CBayFinalTMDLSectio n7 final.pdf.

${ }_{4}^{4} \overline{3}$ U.S.C. $\S 1311$.

${ }^{5} 40$ C.F.R. $\S 131.11$.

633 U.S.C. $\S 1313(d)(1)(c) ; 40$ C.F.R. $\S 130.7(c)(1)$.

7 See, e.g., Del. DeP'T of Natural Res. And Envtl. Control, Chesapeake Bay 20142015 Milestones,

http://www.dnrec.delaware.gov/swc/wa/Documents/ChesapeakePhaseIIWIP/Milestones/

DE_Programmatic_Milestones_2015_FINAL.pdf (last visited June 27, 2014).

${ }^{8}$ See, e.g., DisTRICT DeP'T OF THE ENV'T, January 1, 2014-December 31, 2015 District of Columbia Programmatic Two-Year Milestones, http://www.epa.gov/reg3wapd/pdf/pdf_chesbay/2yearmilestones/2014updates/DC_Progr ammaticMilestones 14-15 FINAL.pdf (last visited June 27, 2014).

${ }^{9}$ See, e.g., VA. DeP'T OF ENVTL. QuAlity, Virginia's 2014-2015 Chesapeake Bay Nutrient and Sediment Reduction Milestones, http://www.deq.virginia.gov/Portals/0/DEQ/Water/ChesapeakeBay/CBTMDL-20142015 ProgrammaticMilestones.pdf (last visited June 27, 2014).

${ }^{10}$ See, e.g., id.

${ }^{11}$ See, e.g., Del. DeP'T of Natural Res. And Envtl. Control, Chesapeake Bay 2014 2015 Milestones, http://www.dnrec.delaware.gov/swc/wa/Documents/ChesapeakePhaseIIWIP/Milestones/ DE_Programmatic_Milestones_2015_FINAL.pdf (last visited June 27, 2014).

12 2012-13 Milestone Commitments:

Washington, D.C., http://www.epa.gov/reg3wapd/pdf/pdf_chesbay/2yearmilestones/DC2012 13Programmat icMilestonesFinalMay2012.pdf.

Delaware, http://www.dnrec.delaware.gov/swc/wa/Documents/ChesapeakePhaseIIWIP/Milestones/ DE_ProgrammaticMilestones_2013update.pdf.

Maryland, http://www.mde.state.md.us/programs/Water/TMDL/TMDLImplementation/Documents/ Milestones/2012-2013/Implementation_2013_Milestones_Rev_final_033012_2.pdf.

New York, http://www.dec.ny.gov/docs/water_pdf/nyfinal13ms.pdf. 
Pennsylvania, http://files.dep.state.pa.us/Water/Chesapeake\%20Bay\%20Program/ChesapeakePortalFile s/4-2-2012/20122013\%20FINAL $\% 20 \mathrm{PA} \% 20$ Two $\% 20$ year $\% 20$ milestones $\% 20$ template $\% 20$ jurisdictions \%20programatic\%203-30-12\%20-\%20Clean.pdf. Virginia, http://www.deq.virginia.gov/Portals/0/DEQ/Water/ChesapeakeBay/CBTMDL2012-2013Milestones-closeout.pdf.

West Virginia, http://www.wvca.us/bay/files/bay documents/289 Annual\%20report\%20Dec\%2031\%20 2012.pdf

\section{${ }^{13}$ EPA Feedback on 2012-13 Milestone Commitments:}

Washington, D.C., http://www.epa.gov/reg3wapd/pdf/pdf_chesbay/Phase2WIPEvals/DCWIPMilestoneEval uation21512 final.pdf.

Delaware, http://www.epa.gov/reg3wapd/pdf/pdf_chesbay/Phase2WIPEvals/DEWIPMilestoneEval uation21512_final.pdf.

Maryland, http://www.epa.gov/reg3wapd/pdf/pdf_chesbay/Phase2WIPEvals/MDWIPMilestoneEval uation21512_final.pdf.

New York (not available)

Pennsylvania, http://www.epa.gov/reg3wapd/pdf/pdf_chesbay/Phase2WIPEvals/PAWIPMilestoneEvalu ation2152012_final.pdf.

Virginia, http://www.epa.gov/reg3wapd/pdf/pdf_chesbay/Phase2WIPEvals/VAWIPMilestoneEval uation21512_final.pdf.

West Virginia, http://www.epa.gov/reg3wapd/pdf/pdf_chesbay/Phase2WIPEvals/WVWIPMilestoneEval uation21512 final.pdf.

${ }^{14}$ This disclosure allows citizens and outside groups to check up on a state's progress. For example, in June 2014, the Choose Clean Water Coalition and Chesapeake Bay Foundation released a useful progress report based on this public information.

CheSAPEAKE BAY FDn., Milestones: Updates by State, http://www.cbf.org/milestones (last visited June 27, 2014).

\section{${ }^{15}$ 2014-15 Milestone Commitments:}

Washington, D.C., http://www.epa.gov/reg3wapd/pdf/pdf_chesbay/2yearmilestones/2014updates/DC_Progr ammaticMilestones_14-15_FINAL.pdf.

Delaware, http://www.dnrec.delaware.gov/swc/wa/Pages/Delaware-WIP-ChesapeakeBay-Milestones.aspx.

Maryland, http://www.mde.state.md.us/programs/Water/TMDL/ChesapeakeBayTMDL/Pages/progr ams/waterprograms/tmdl/cb tmdl/index.aspx.

New York, http://www.dec.ny.gov/lands/33279.html. 
Pennsylvania,

http://www.epa.gov/reg3wapd/pdf/pdf_chesbay/2yearmilestones/2014updates/PA2014-

2015FinalProgrammaticMilestones.pdf.

Virginia,

http:/www.deq.virginia.gov/Programs/Water/ChesapeakeBay/ChesapeakeBayWatershed

ImplementationPlan.aspx.

West Virginia, http://www.wvca.us/bay/tmdl.cfm.

${ }^{16}$ Envtl. Protection Agency, Fact Sheet: EPA Assessment of Chesapeake Bay 2012-

2013 Milestone Progress and 2014-2015 Milestone Commitments to Reduce Nitrogen,

Phosphorous and Sediment,

http://www.epa.gov/reg3wapd/tmdl/2014Evaluations/factsheet Overall.pdf (last visited

July 1, 2014).

${ }^{17} I d$.

${ }^{18}$ Envtl. Protection Agency, EPA Evaluation of Delaware's 2012-2013 and 20142015 Milestones (June 26, 2014),

http://www.epa.gov/reg3wapd/tmdl/2014Evaluations/DE.pdf.

${ }^{19}$ Envtl. Protection Agency, EPA Evaluation of Pennsylvania's 2012-2013 and

2014-2015 Milestones (June 26, 2014),

http://www.epa.gov/reg3wapd/tmdl/2014Evaluations/PA.pdf.

${ }^{20}$ See, e.g., EnVtl. Protection AgEnCy, ChesaPEAKe BAy TMDL, Executive

Summary, ES-10 to ES-11 (Dec. 29, 2010), available at

http://www.epa.gov/reg3wapd/pdf/pdf_chesbay/FinalBayTMDL/CBayFinalTMDLSectio $\mathrm{n} 7$ final.pdf.

${ }^{21}$ Envtl. Protection Agency, EPA Evaluation of the District of Columbia's 2012 2013 and 2014-2015 Milestones (June 26, 2014),

http://www.epa.gov/reg3wapd/tmdl/2014Evaluations/DC.pdf.

22 Envtl. Protection Agency, EPA Evaluation of Delaware 's 2012-2013 and 20142015 Milestones (June 26, 2014),

http://www.epa.gov/reg3wapd/tmdl/2014Evaluations/DE.pdf.

${ }^{23}$ Envtl. Protection Agency, EPA Evaluation of Maryland's 2012-2013 and 20142015 Milestones (June 26, 2014),

http://www.epa.gov/reg3wapd/tmdl/2014Evaluations/MD.pdf.

${ }^{24}$ Envtl. Protection AgEnCY, EPA Evaluation of New York's 2012-2013 and 20142015 Milestones (June 26, 2014),

http://www.epa.gov/reg3wapd/tmdl/2014Evaluations/NY.pdf.

${ }^{25}$ Envtl. Protection Agency, EPA Evaluation of Pennsylvania's 2012-2013 and

2014-2015 Milestones (June 26, 2014),

http://www.epa.gov/reg3wapd/tmdl/2014Evaluations/PA.pdf.

${ }^{26}$ EnVtL. Protection AGENCY, EPA Evaluation of Virginia's 2012-2013 and 20142015 Milestones (June 26, 2014),

http://www.epa.gov/reg3wapd/tmdl/2014Evaluations/VA.pdf.

27 Envtl. Protection Agency, EPA Evaluation of West Virginia's 2012-2013 and 2014-2015 Milestones (June 26, 2014),

http://www.epa.gov/reg3wapd/tmdl/2014Evaluations/WVA.pdf. 
Founded in 2002, the Center for Progressive Reform is a 501(c)(3) nonprofit research and educational organization comprising a network of scholars across the nation dedicated to protecting health, safety, and the environment through analysis and commentary. CPR believes sensible safeguards in these areas serve important shared values, including doing the best we can to prevent harm to people and the environment, distributing environmental harms and benefits fairly, and protecting the earth for future generations. CPR rejects the view that the economic efficiency of private markets should be the only value used to guide government action. Rather, CPR supports thoughtful government action and reform to advance the well-being of human life and the environment. Additionally, CPR believes people play a crucial role in ensuring both private and public sector decisions that result in improved protection of consumers, public health and safety, and the environment. Accordingly, CPR supports ready public access to the courts, enhanced public participation, and improved public access to information.

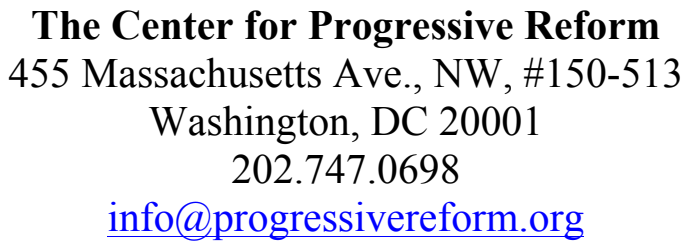

Direct media inquiries to Matthew Freeman or Erin Kesler, 202.747.0698, mfreeman@progressivereform.org or ekesler@progressivereform.org.

Visit CPR on the web at www.progressivereform.org. Read CPRBlog at www.progressivereform.org/CPRBlog.cfm.

\section{Acknowledgements}

CPR is grateful to the Town Creek Foundation and the Rauch Foundation for their support of this project. This Issue Alert is a collaborative effort of the following CPR Member Scholars and staff:

- Rena Steinzor is a Professor of Law at the University of Maryland Francis King Carey School of Law.

- Anne Havemann, J.D., is the Chesapeake Bay Policy Analyst at the Center for Progressive Reform. 